\title{
Clinical, serological and antigenic study of feline panleukopenia virus in cats in Baghdad, Iraq
}

\author{
M.M. Zenad ${ }^{1}$ and A.M. Radhy ${ }^{2}$
}

Department of Internal and Preventive Veterinary Medicine, College of Veterinary Medicine, University of Baghdad, Baghdad, Iraq, Email: ${ }^{1}$ Zenadaboodi@yahoo.com, ${ }^{2}$ sarmadmazda@gmail.com

(Received July 22, 2019; Accepted September 30, 2019; Available online August 4, 2020)

\begin{abstract}
(FPL) is a common contagious disease with high morbidity and mortality rates. This study was performed in the Baghdad capital city of Iraq from January 2018 -to- February 2019. Fecal and blood samples were collected from both diarrheic and nondiarrheic 180 cats, of both sexes. Hundred pet and eighty stray cats was divided into 2 groups according to their ages: > 1-year and < 1-year. Fecal sample were checked for presence of FPL virus antigens by rapid antigen test kit (immunochromatography assay) and blood samples were tested for presence of FPL virus specific antibodies by ELISA test as well as the study of blood parameters of cats. Forty cats $22.2 \%$ were infected with FPL virus by ICG assay, while a high percentage of total seropositive rate $65(36.1 \%)$ was founded by ELISA test. Significant higher infection $27.5 \%$ and seropositive $36.7 \%$ rates were observed in cats less than one-year age. Clinically the infected cats showed multi-systemic signs and the vomiting was the more frequent sign $87.5 \%$, hematological changes showed significant decrease in hemogram values and prolonged clotting time, the total leukocytic count was lowered in infected cats and this owing to significant decrease in absolute numbers of lymphocytes and neutrophils. In conclusion FPL virus was widely spread in Baghdad and higher infection rate was recorded in a stray cat.
\end{abstract}

Keywords: Feline panleukopenia, FPL virus, ICG, ELISA, Iraq

DOI: 10.33899/ijvs.2019.125960.1201, (C) 2020, College of Veterinary Medicine, University of Mosul.

This is an open access article under the CC BY 4.0 license (http://creativecommons.org/licenses/by/4.0/).

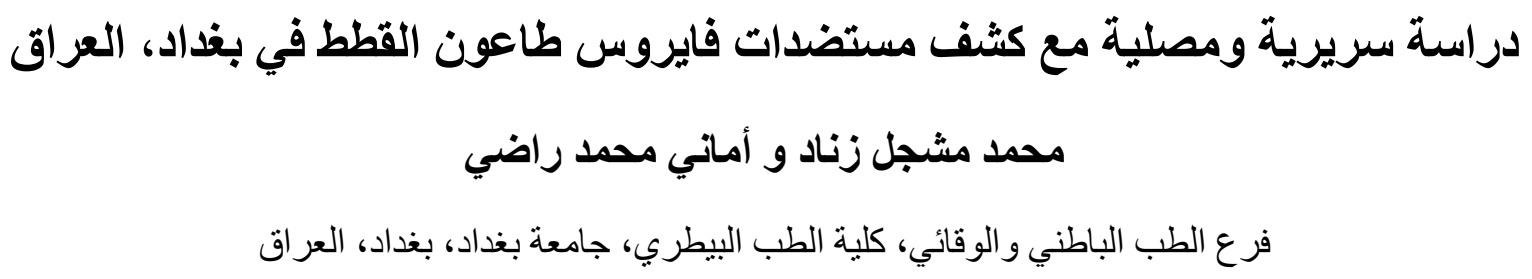

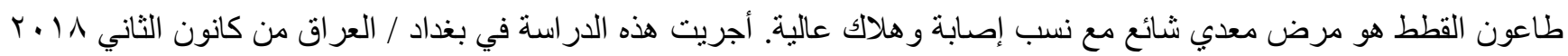

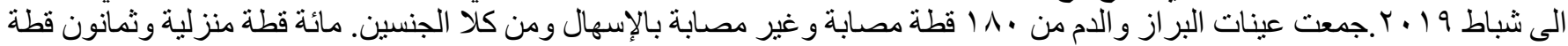

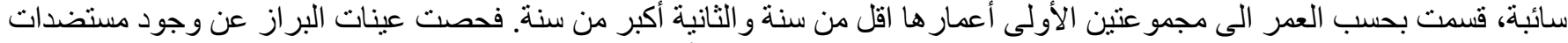

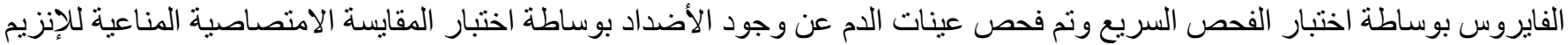

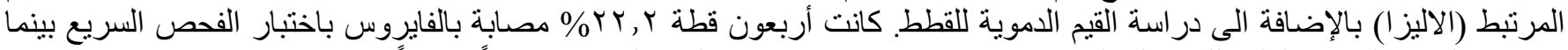

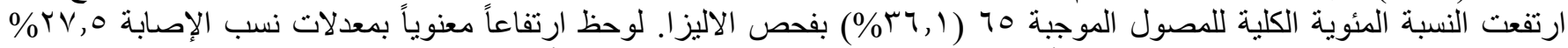

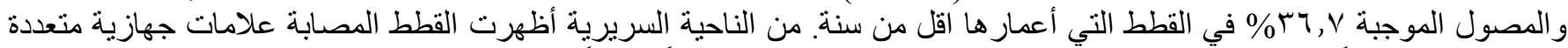

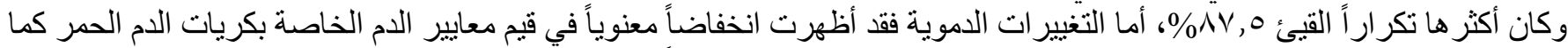

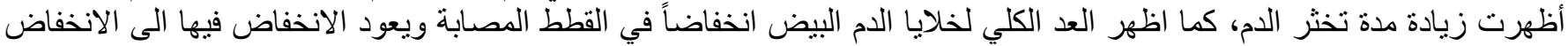

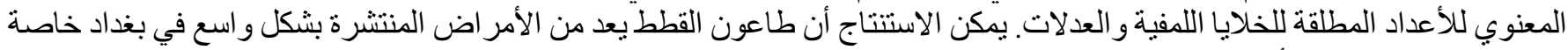
في القطط السائبة ولهذا فأن السيطرة على المرض تحتاج الى منع تفشي المرض في هذه القطط. 


\section{Introduction}

Feline panleukopenia (FPL) is a highly sever contagious viral infection of cats. It is a destructive disease of kittens although cats of all ages are susceptible to infection (1). The severity of disease depends on the immune status of population; in those, vaccination is routinely practice, few cats may be infected, whereas in non-vaccinated population the morbidity rate reaches nearly to $100 \%$ (2). The disease is manifested clinically by multiple systemic signs including: digestive dysfunction, neural disorders and reproductive failure; as abortion, stillbirth and early neonatal deaths more over neutropenia and lymphopenia are commonly observed in infected cats (3). The FPL virus is belonged to the Parvoviridae family, a linear single stranded DNA virus (4). FPL virus is very stable and remains infective at room temperature for a year on fomites and organic materials (5). Furthermore, the FPL virus most commonly transmitted by direct contact with infected animals and their secretions. The flies and other insects have roles in spreading of the virus during worm weather (6). The virus is mostly recovered from intestine and feces, and this might be belonging to its tropism in highly dividing cells (2). Several laboratory techniques were used for diagnosis of FPL virus, the immunochromatography (ICG) assay is a very rapid field test, the relative sensitivity and specificity were $95.8 \%$ and 99.7\% respectively (7). In Iraq AL- Bayati (8) it was recorded an infection rate $38 \%$ in diarrheic cats, the very close rate of infection (34\%) in diarrheic cats was reported in a neighboring country Iran Mosallanejad et al. (9). Lowest rate of infection 22.9\% was reported in Bangladesh Islam et al. (10). High prevalence rate $48 \%$ was recorded in free ranging Cheetahs in Namibia Munson et al. (11). FPL virus was recorded also in European countries: in Belgium Garigliany et al. (12) and Italy Decaro et al. (13).

The current study was carried out to detect FPL virus in Baghdad by immune chromatography assay and ELISA with referring to clinical and hematological changes in the infected cats.

\section{Material and methods}

This study was performed in Baghdad, Iraq, in the period from January 2018 - to - February 2019, under the consent of Baghdad University Council. Fecal and blood samples were collected from both diarrheic and non-diarrheic 180 cats, of both sexes. One hundred pet (house hold cats) and eighty stray cats, were divided according to their ages in to: more than one $(<1)$ year and less than one $(>1)$ year. The historical data of pet cats were reported. The stray cats were restrained by administration of Anestane ${ }^{\circledR}$ (Halothane 100\% Bp stabilized by $0.01 \%$ thymol) and xylazine $0.15 \mathrm{mg} / 1 \mathrm{~kg}$ for anesthesia (14). Fecal swabs were taken aseptically from all cats. Four milliliters of blood were obtained from medial saphenous vein, and divided equally in to two tubes: first provided with ethylene diamine tetra acetic acid (EDTA), for complete blood count (CBC) using blood analyzer and the other left without anticoagulant for serum collection, which achieved by centrifugation for $3000 \mathrm{rpm}$ for 10 minutes. FPL virus detection was carried out by ICG according to company instruction manual. The indirect test for detection of FPL virus specific antibodies had been done by ELISA chromatography according to the manufacture company, the samples were reading by ELISA Reader spectrophotometer (Biotak, USA) at $450 \mathrm{~nm}$. Statistical analysis of data was done by using $\mathrm{T}$ test one-way ANOVA and Chi- Square test (15) and the significance was considered at $\mathrm{P} \leq 0.05$.

\section{Results}

Forty fecal samples $22.2 \%$ were positive to the ICG assay, and this rate was significantly lower than the rate of seropositivity for presence of FPL virus antibodies by ELISA 65 (36.1\%) (Table 1).

A higher infection rate was recorded by ICG Assay in stray cats $26.2 \%$ as compared with the pet house hold cats $19 \%$. Furthermore, a significantly higher seropositive pet cats were recorded $38 \%$ (Table 2).

Table 1: Percentage of positive Sera for specific antibodies and feces for presence of FPL virus antigen in cats

\begin{tabular}{lccc}
\hline Test & Samples & No. samples & No. positive (\%) \\
\hline ICG & feces & 180 & $40(22.2 \%)$ \\
ELISA & Serum & 180 & $65(36.1 \%)^{*}$ \\
\hline
\end{tabular}

${ }^{*}$ Significant at $\mathrm{P} \leq 0.05$.

Table 2: Percentage of cats for FPL virus specific antibodies and its antigen

\begin{tabular}{|c|c|c|c|}
\hline \multirow{2}{*}{ Population } & \multirow{2}{*}{ No. cats } & \multicolumn{2}{|c|}{ Positive cases (\%) } \\
\hline & & ICG & ELISA \\
\hline Pet cats & 100 & $19(19)^{*}$ & $38(38)^{*}$ \\
\hline Stray cats & 80 & $21(26.3)$ & $27(33.8)$ \\
\hline
\end{tabular}

${ }^{*}$ Significant difference at $\mathrm{P} \leq 0.05$.

Despite the non-significant effect of sex variation on both infection and seropositivity rates were observed, the age difference had markedly influenced both seropositive and infection rates. The significant higher infection $27.5 \%$ and seropositive rates $36.7 \%$ were observed in less than one year old (Table 3).

Many infected cats showed two or more clinical signs, these were subsequently vomiting $87.5 \%$, fever $75 \%$, other clinical signs included nervous signs $65 \%$, mouth lesion $50 \%$, eye lesion $47.5 \%$, and diarrhea $44 \%$ which was a less frequent sign (Table 4) (Figures 1-3). 
Table 3: Effect of sex and ages on infection of cats with FPL virus

\begin{tabular}{|c|c|c|c|c|}
\hline \multirow{2}{*}{ Factors } & \multirow{2}{*}{\multicolumn{2}{|c|}{ No. of cases }} & \multicolumn{2}{|c|}{ Positive cases and $\%$} \\
\hline & & & ICG & ELISA \\
\hline \multirow[b]{2}{*}{ Sex } & Male & 80 & $17(21.3)$ & $27(33.8)$ \\
\hline & female & 100 & $23(23)$ & $38(38)$ \\
\hline \multirow{2}{*}{ Age } & $>1$ year & 98 & $27(27.6)^{\mathrm{a}}$ & $36(36.7)^{\mathrm{b}}$ \\
\hline & $<1$ year & 82 & $13(15.9)^{c}$ & $29(35.4)^{d}$ \\
\hline
\end{tabular}

Different letters: Significant difference at $\mathrm{P} \leq 0.05$.

Table 4: Clinical signs appeared in forty infected cats with FPL virus detected by ICG assay

\begin{tabular}{lcc}
\hline Sign & No. & $\%$ \\
\hline Vomiting & 35 & 87.5 \\
Fever & 30 & 75 \\
Nervous Sign & 26 & 65 \\
Mouth lesion & 20 & 50 \\
Eye lesion $^{*}$ & 19 & 47.5 \\
Diarrhea & 22 & 44 \\
\hline
\end{tabular}

"Eye lesion including: Blindness 4 (10\%), Conjunctivitis 10 (25\%), Corneal opacity 5 (12.5\%).

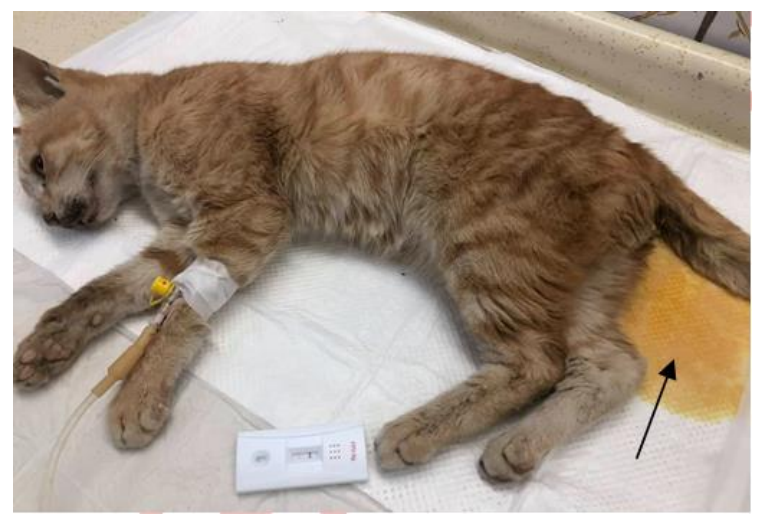

Figure 1: Cat showed severe enteritis; +ve for FPL virus infection by ICG.

The blood parameters showed significant lowering values among hemogram in the infected cats: packed cell volume $25 \pm 0.68 \%$, hemoglobin $8.33 \pm 0.18 \mathrm{~g} / \mathrm{dl}$, red blood count $5.84 \pm 0.26 \times 10^{12} / \mathrm{L}$, platelets count $426.05 \pm 31.01 \times 10^{9}$ /L. Consequently, the clotting time was prolonged 5.39 \pm 0.18 minute in infected cats as compared with non-infected $3.93 \pm 0.92$ minutes (Table 5).

The significant decrease in the value of the total leukocytic count to a less extent $1.86 \pm 0.63 \times 10^{9} / \mathrm{L}$ was observed in the infected cats, such lowering in the total leukocytic count was belonging to a significant decrease in the absolute number of both lymphocytes $27.31 \pm 1.81 \times 10^{9} / \mathrm{L}$ and neutrophils $42.13 \pm 1.77 \times 10^{9} / \mathrm{L}$ (Table 6).

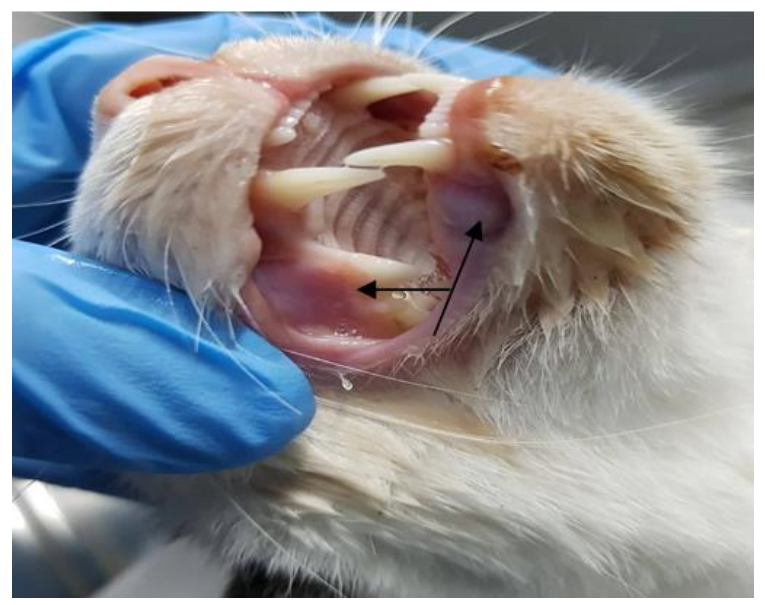

Figure 2: Cat showed swollen and ulceration in the mouth; +ve for FPL virus infection by ICG.

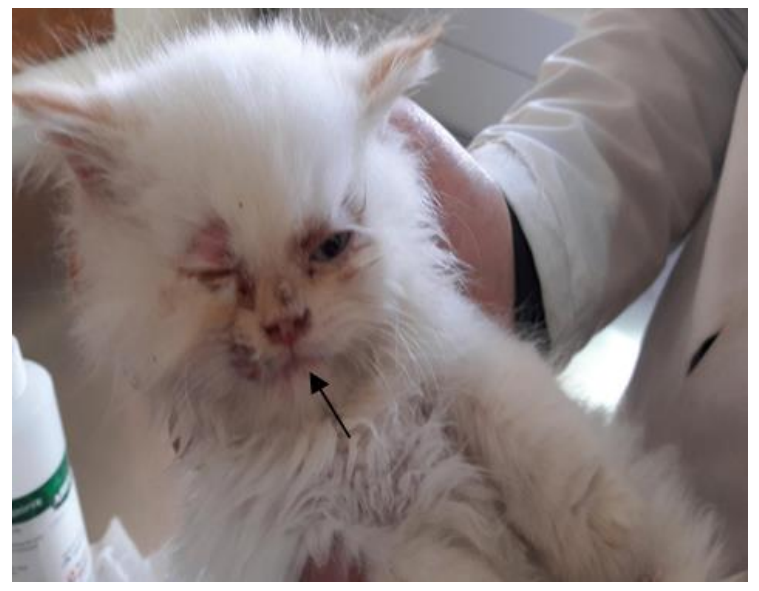

Figure 3: Showed chronic eye lesion in cat infected with FPL by ICG assay.

Table 5: Blood parameters of infected and non-infected cats with FPL virus detected by ICG assay

\begin{tabular}{lcc}
\hline Parameter & Infected & Non infected \\
\hline PCV & $20-32$ & $26-44$ \\
$(\%)$ & $25 \pm 0.68^{*}$ & $32.70 \pm 0.53$ \\
$\mathrm{Hb}$ & $6.90-10$ & $8-13.20$ \\
$(\mathrm{~g} / \mathrm{dl})$ & $8.33 \pm 0.18^{*}$ & $10.18 \pm 0.13$ \\
$\mathrm{RBCs}$ & $4.38-8.9$ & $5.12-11.50$ \\
$\left(\mathrm{X} 10^{12} \backslash \mathrm{L}\right)$ & $5.84 \pm 0.26^{*}$ & $7.54 \pm 0.14$ \\
Platelets & $217-761$ & $997-1013$ \\
$\left(\mathrm{X} \mathrm{10} 0^{9} \mathrm{~L}\right)$ & $426.05 \pm 31.01^{*}$ & $504.38 \pm 29.86$ \\
Clotting time & $4-7$ & $2-5$ \\
(minute) & $5.39 \pm 0.18^{*}$ & $3.93 \pm 0.92$ \\
\hline
\end{tabular}

${ }^{*}$ Significant at $\mathrm{P} \leq 0.05$. 
Table 6: Total and differential leukocytic count in infected and non-infected cats with FPL virus detected by ICG assay

\begin{tabular}{lcc}
\hline Parameter & Infected & Non infected \\
\hline \multirow{2}{*}{ TLC } & $6.11-18.40$ & $8.31-23.68$ \\
& $11.86 \pm 0.63^{*}$ & $15.92 \pm 12.01$ \\
Lymphocyte & $11-46$ & $17-64$ \\
& $27.31 \pm 1.81^{*}$ & $35.74 \pm 1.14$ \\
Neutrophils & $27-60$ & $36-84$ \\
& $42.13 \pm 1.77^{*}$ & $54.69 \pm 1.17$ \\
Monocyte & $0-3$ & $0-6$ \\
Eosinophil & $1.26 \pm 0.17$ & $2.36 \pm 0.16$ \\
& $0-7$ & $0-12$ \\
Basophile & $3.89 \pm 0.34$ & $4.15 \pm 0.27$ \\
& $0-1$ & $0-1$ \\
& $0.52 \pm 0.82$ & $0.43 \pm 0.42$ \\
\hline
\end{tabular}

* Significant at $\mathrm{P} \leq 0.05$.

\section{Discussion}

Detection of FPL virus infection is an important for diagnostic purposes and for control of infection, particularly in low facilities against treatment of virus infection (7). Rapid diagnosis of FPL Virus is necessary for quick isolation of infected cats, also for prevention of secondary infection of susceptible cats. The ICG test is an efficient rapid test for FPL virus detection (9).

The infection rate of FPL in cats by ICG was $22.2 \%$, although high infection rats was recorded in diarrheic cats $38 \%$ in Iraq Al-Bayati (8), in the same instance a close rate of infection 34\% was recorded in diarrheic cats, in neighboring country Iran Mosallanejad et al. (9). Moreover, a very close infection rate of FPL $22.2 \%$ to our findings was reported in Bangladesh Isalm et al. (10). Also, low rate of FPL Virus infection in cats $13.3 \%$ was reported in India Mayur et al. (16). In contrary higher infection rate $48 \%$ was recorded in free cheetahs in Namibia Munson et al. (11).

The variations in infection rates were belonged to different environmental conditions and techniques used in various studies in different locations, besides presence and absence of many factors as age, health and immune status of host, influenced the rates of infections (17).

Furthermore, the infection rate with FPL virus in stray cats $26.2 \%$ was higher than pet house hold cats $19 \%$, this was compatible to other studies a low rate of infection in pet $4 \%$ than in stray cats was reported in Nigeria Bukar - Kolo et al. (18), this probably might owing to the management and care of pet cats breeders, particularly they are depending routinely vaccination programs, whereas the stray cats had a great chance of exposure to many infectious agents, as they are moving, eating and drinking freely. Thus, stray cats serve as source of infection to other felines (8). Beside that the stray cats don't subjected to vaccination program against any pathogens, so that probably makes them more vulnerable to FPL virus infection.

High total seropositive cats for FPL virus specific antibodies $36.9 \%$ were recorded in the current study, indeed a significant higher seropositive rate was observed in pet cats $38 \%$ and $33.7 \%$ in stray cats. The elevation of seropositive rate in pet cat might be belonged to implication routine vaccinating program. The stray cats also showed no significant increase in the rate of seropositivity to FPL virus antibodies, the nature of their free life might contribute in the exposure of theses cats to FPL virus antigen, which in turn increase specific antibody formation to limit extent.

The high rate of FPL virus infection and seropositive cats in the current study were really reflecting the high diversity of FPL virus in Baghdad city. Thus, the control program of FPL virus infection requires including both stray and pet cats in the considered control plane.

In the same instance the young cats (less than one year) showed a significant increase in both infection $27.5 \%$ and seropositive rates $36.7 \%$, these were in agreement with many authors $(10,19,20)$. Sex variation had no significant effect on infection and seropositive rates.

Despite the FPL virus was detected in feces of infected cats but the most frequent sign was vomiting $87.5 \%$. However many researches stated that diarrhea is a prominent sign and the FPL virus was shedding with feces mostly in diarrheic cats $(8,9)$, which might be caused by other causative agents that helping the virus to produce its pathogenic effect in the intestinal epithelial tissue, which leading to damage of intestinal crypts and finally facilitate the excretion of virus particularly in non-vaccinated cats (2).

It seemed to be that FPL virus has ability to invade multi systemic tissues and organs, causing a variety of symptoms, the frequency and severity of these signs probably depend on many factors related to the host and other environmental factors (3). Beside that the tropism the virus for progenitor and highly dividing cells, may increasing the invasion of many systems including these cells (21).

Similarly, as the blood changes showed an obvious decrease in $\mathrm{RBCs} 5.84 \pm 0.26 \times 0^{12} / \mathrm{L}$, also a significant lowered platelets count was recorded infected cats, these might be attributed to damage of progenitor cells in bone marrow (22). Consequently, the clotting time was prolonged $5.39 \pm 0.18$ /minute in an infected cat. Moreover, the diminution of platelets numbers may influence the immune response of infected host (23), thus all systems in the of host will showed impaired of defense mechanisms, this might be responsible for appearing of multi systemic signs.

Furthermore, many authors reported leukopenia, which are in agreement with our findings (18). The significant low leukocytic count $11.86 \pm 0.63$ was observed in infected cats also effectively contributed in disturbance of defense mechanism, so that the infected host can't get rid of viral 
pathogenic agent, this was supporting the appearance of multiple clinical signs.

\section{Conclusion}

The high spread of FPL virus in Baghdad requires, vaccination of both pet and stray cats and a hygienic procedure are important measures for the prevention of FPV infections in the companion cat population, as well as the study of the effectively of commercial vaccines to protect against FPL virus.

\section{Acknowledgments}

I would like to express my deepest faithful thanks to the all veterinarians in Vet Clinic and Baghdad Vet. Hospital in Baghdad province and Al-Rawan Corner Office for the assistance provided in carrying out my research.

\section{Conflict of interest}

The authors declare that there are no conflicts of interest regarding the publication of this manuscript.

\section{References}

1. Truyen, U, Agbandje M, Parrish C R. Characterization of the feline host range and a specific epitome of feline panleukopenia virus. Virology.1994; 200:494 - 503. 10.1006/viro.1994.1212

2. Greene CE, Addie DD. Feline parvovirus infections. In: Greene CE, editor. Infectious diseases of the dog and cat. St. Louis: Saunders Elsevier; 2006. 78-88 p.

3. Alleice S. Feline panleukopenia (feline distemper): Common diseases of companion animals. $3^{\text {rd }}$ ed. St. Louis: Elsevier Health Sciences Division; 2014. 163-164 p.

4. Parrish CR. Parvoviruses: cats, dogs and mink. In: Webster RG, Granoff A, editors. Encyclopedia of virology. London: Academic Press; 1994. 1061-1067 p.

5. Goto H, Horimoto M, Shimizu K, Hariga T, Matsuoko T, Nakano T, Moronushi Y, Maejing K, Urano, T. Seroprevalence of feline panleukopenia virus in domestic cat. J Environ Dis. 2006;15:1-2. $10.1155 / 2012 / 356798$

6. Inada S, Mochizuk M, Izumo S, Kuriyama M, Sakamoto H, Kawasaki Y, Osame M. Study of hereditary cerebellar degeneration in cats. Am J Vet Res. 1996;57:296-301. https://pubmed.ncbi.nlm.nih.gov/8669758/

7. Esfandiari J, Klingeborn B. A comparative study of a new rapid and one-step test for the detection of parvovirus in faeces from dogs, cats and mink. J Vet Med B Infect Dis Vet Pub Heal. 2000;47:145-153. 10.1046/j.1439-0450.2000.00328.x

8. Al-Bayati HAM. Detection of feline parvovirus (FPV) from cats infected with enteritis using rapid test and polymerase chain reaction in Iraq. Kufa J Vet Med Sci. 2016;7(2):61-70.

9. Mosallanejad B, Avizeh R, Ghorbanpoor Najafabadi M. Antigenic detection of feline panleukopenia virus (FPV) in diarrhoeic companion cats in Ahvaz area. Iranian J Vet Res. 2009;28:289-293.

10. Islam MA, Rahman MS, Ray SR, Uddin MJ, Rahman AM. Antigenic infection of feline panleukopenia virus in local breeds' cats at Tanguil district in Bangladesh. Int J Biol Res. 2010;2(11)25-28.

11. Munson L, Market L, Dubovi E, Spencer J A. Sero-survey of viral infection in free ranging Namibian cheetahs. $J$ Wildlife Dis. 2004;40(1):23-31. 10.7589/0090-3558-40.1.23

12. Garigliany M, Gilliaux G, Jolly S, Casanova T, Bayrou C, Gommeren $\mathrm{K}$. Feline panleukopenia virus in cerebral neurons of young and adults' cats. BMC Vet Res. 2016;12(28):1-9. 10.1186/s12917-016-0657-0

13. Decaro N, Desario C, Miccolupo A, Campolo M, Parisi A, Martella V, Amorisco F, Lucente M S, Lavazza A, Buonavoglia C. Genetic analysis of feline panleukopenia viruses from cats with gastroenteritis. J Gen Virol. 2008;89:2290-2298. 10.1099/ vir.0.2008/001503-0

14. Beaver BV, Reed W, Leary S, McKiernan B, Bain F, Schultz R, Bennett BT, Pascoe P, Shull E, Cork LC, Francis-Floyd R, Amass KD, Johnson R, Schmidt RH, Underwood W, Thornton GW, Kohn B. 2000 Report of the AVMA Panel on Euthanasia. JAVMA. 2001;218:669-696 10.2460 / javma.2001.218.669

15. SAS. STAT Users Guide for Personal Computer. Release 9.1. USA: SAS Institute Inc; 2010.

16. Mayur TC, Kamran AC, Ramesh PT. Diagnosis of feline panleukopenia and feline leukemia virus using rapid test kits. Int J Agri Sci Vet Med. 2016;4(3):71-75.

17. Smith R D. Veterinary clinical epidemiology. $3^{\text {rd }}$ ed. Boca Raton: CRC Press; 2005. 97-111 p.

18. Bukar YM, Buba E, Igbokwe IO, Egwu GO. Prevalence of feline panleukopenia virus in pet and stray cats and associated risk factors in Maiduguri, Nigeria. AJVS. 2018;59(1):92-96. 10.5455/ajvs.282457

19. Awad RA, Khalil WKB, Attallah AG. Epidemiology and diagnosis of feline panleukopenia virus in Egypt: Clinical and molecular diagnosis in cats. Vet World. 2018;1(11):578-584. doi: 10.14202/vetworld.2018.578-584.

20. Kim SG, Lee KL, Kim JK, Hee Myong P. Prevalence of feline panleukopenia virus in stray and household cats in Seoul Korea. J Vet Clin. 2013;30(5):333-338. http://www.koreascience.or.kr/article/ JAKO201333959964485.view

21. Greene CE. Infectious diseases of the dog and cat. $4^{\text {th }}$ ed. Missouri: Saunders; 2012.

22. Breuer W, Stahr K, Majzoub M, Hermanns W. Bone marrow changes in infectious diseases and lymph haemopoietic neoplasia in dogs and cats: A retrospective study. J Comp Pathol. 1998;119:57-66. 10.1016/s0021-9975(98)80071-6.

23. Banchereau J, Briere F, Caux C, Davoust J, Lebecque S, Liu YJ, Pulendran B, Palucka K. Ann Rev Immuno. 2000;18:767. 10.1146 / annurev.immunol.18.1.767 